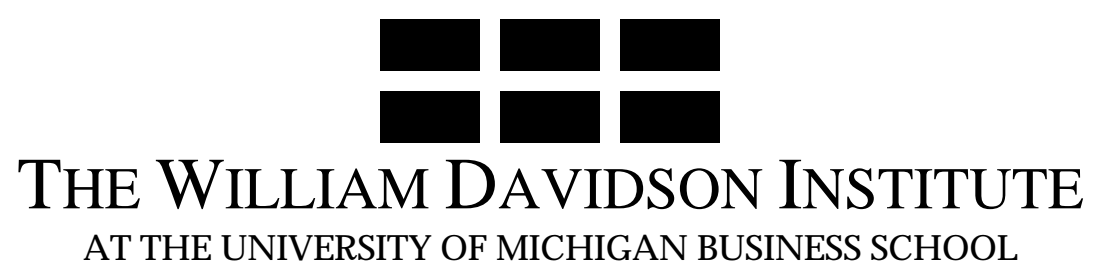

\title{
Accounting for Growth in Post-Soviet Russia
}

by Daniel Berkowitz and David N. DeJong

Working Paper Number 127

June 1999

\section{Comments Welcome}

Copyright Daniel Berkowitz and David N. DeJong, 1998. Disseminated by the Davidson Institute with permission of the authors. 


\title{
Accounting for Growth in Post-Soviet Russia
}

\author{
Daniel Berkowitz and David N. DeJong \\ Department of Economics; University of Pittsburgh; Pittsburgh, PA 15260 \\ dmberk+@pitt.edu; dejong+@pitt.edu
}

First version: January 1998

This revision: June 1999

\begin{abstract}
In pursuit of its transition from a command to a market economy, post-Soviet Russia has witnessed enormous regional differences in economic growth rates. Moreover, the economic reforms implemented under this transition, while initiated at the federal level, have also differed markedly across regions, as regional governments have had considerable discretion over the implementation of reform policies in their jurisdictions. We exploit these differences in analyzing whether regional differences in reform policies can account for regional differences in growth rates, and conclude that to a considerable degree, they can. Most notably, we find that local-government privatization initiatives and regional-government initiatives to gain control over their capital stock (e.g. plants, equipment, machinery and social infrastructure) exhibit close correspondence with the formation of new legal enterprises, which in turn exhibits close correspondence with economic growth.
\end{abstract}

Acknowledgments: We thank Anders Aslund, Gleb.Bylov, Lev Freinkman, Yelena Borisovna Frolova, Clifford Gaddy, Evgeny Gavrilenkov, Timothy Heleniak, Alastair McAuley, Randi Ryterman and especially Nina Chebotarieva for their help with the data used in this study. We also thank Patty Beeson, Olivier Blanchard, Martha de Melo, Richard Ericson, Roger Gordon, John Ham, Hide Ichimura, Peter Murrell, Thomas Rawski, Jean-Francois Richard, Thomas Richardson, Andrei Shleifer, Lara Shore-Sheppard, Rick Tannery, Werner Troesken, and participants in the $1998 \mathrm{AEA} / \mathrm{ACES}$ panel on fiscal federalism in transition economies for many useful comments. We are particularly grateful to Steve Husted and Alexei Lavrov for their input. For providing financial support, Berkowitz is indebted to the National Council for Soviet and East European Studies (under contracts \#807-09 and \#811-12); the National Science Foundation (under grant SBR-9730499); and the University of Pittsburgh. DeJong gratefully acknowledges financial support provided by the NSF under grant SBR-9422828. The usual caveat applies.

Keywords: new-enterprise formation, economic growth, regional reform initiatives, decentralization. 


\section{Accounting for Growth in Post-Soviet Russia}

"... the revival of the private sector is among the most important changes that take place in the socialist system during the process of reform." (Janos Kornai, 1992, p.459)

\section{Introduction}

The economic reforms implemented in Post-Soviet Russia have coincided with a surge in the establishment of new private enterprises. These enterprises consist of start-ups and spin-offs from stateowned enterprises. They tend to be small, legally registered, and concentrated in construction, trade, commerce, and small-scale industry. Kornai $(1990,1992)$ argues that new-enterprise formation is critical for generating growth in post-socialist economies. The crux of his argument is that new enterprises are relatively free of the kinds of distorted incentives that influence state-owned enterprises, and are therefore relatively efficient and responsive to market conditions. ' In addition, Blanchard (1997) notes that by providing expanded employment opportunities, new enterprises better enable politicians to implement efficiency reforms (such as the hardening of state-sector budget constraints) that reduce state-sector employment without losing political support. Finally, Blanchard and Kremer (1997) emphasize the importance of new-enterprise formation in mitigating output reductions resulting from the restructuring and privatization of state enterprises, and breakdowns in the state supply system.

The purpose of this paper is to quantify the relationship between new-enterprise formation and economic growth in Post-Soviet Russia, and to explore the influence of various reform policies on this relationship. We do this using a regional data set that includes information on new-enterprise formation, growth in real per capita income, and a host of policy-reform measures for 47 regions in Russia. The data span the period 1993:IV - 1996:IV, and are described in Section 2. There was considerable regional variation in new-enterprise formation, growth experiences, and the implementation of policy reforms over this period; this variation yields several interesting insights.

Figures 1 and 2 are suggestive of our main findings. Figure la plots annual average growth rates against our baseline measure of new-enterprise formation (new firms per thousand inhabitants) for our full sample of regions. It also plots the fitted line obtained by regressing growth on a constant and new enterprises. A striking aspect of the figure is the wide range of growth experiences observed in our sample: growth rates ranged from -22 percent to 17.3 percent over the sample period. Also notable is the correspondence observed between regional growth and new-enterprise formation. The unconditional correlation between the series is 0.628 . Also, the regression coefficient we obtain implies that the addition of a single new small enterprise per thousand inhabitants corresponds with a 1.79 percentage

\footnotetext{
${ }^{1}$ Our use of the term state-owned enterprises refers to fully state-owned enterprises, as well as "privatized" or "privatizing" state enterprises over which the state retains de facto significant control and ownership rights.
} 
point increase in the regional annual growth rate (the coefficient is statistically significant at the 5-percent level). Figure $1 \mathrm{~b}$ plots growth against new enterprises for a sub-sample of our data set that excludes three apparent outliers (Moscow, St. Petersburg, and the oil-rich Tyumen oblast). These regions benefited from unusually high levels of new-enterprise formation, and also enjoyed above-average growth. Their exclusion reduces the unconditional correlation between the series to 0.281 , but reduces the estimated regression coefficient only slightly, to 1.51 (the coefficient remains significant at the 5-percent level).

Of course, the unconditional relationships illustrated in Figure 1 may be spurious, merely reflecting the joint impact of unmeasured variables on new-enterprise formation and growth. Thus in Figure 2 we plot the portion of regional growth that cannot be explained using the full set of explanatory variables (other than new enterprises) contained in our data set against new enterprises. Specifically, in this case growth is measured as the residual obtained by regressing growth on initial income levels, regional industrial characteristics, and several policy variables described below. Figure 2a presents the resulting conditional relationship obtained using the full data set. The sample correlation is 0.43 in this case, and the coefficient we obtain by regressing the growth residual on a constant and new enterprises is 1.06 (significant at the 5 -percent level). Figure $2 \mathrm{~b}$ presents the conditional relationship observed in the sub-sample of our data set. The relationship between growth and new enterprises appears stronger than in the full sample in this case: the sample correlation is 0.36, and the regression coefficient is 1.38 (again significant at the 5-percent level). The general relationship illustrated in these figures turns out to be robust to a host of considerations outlined below.

If new-enterprise formation has indeed been an important engine of growth in Post-Soviet Russia, it is then critical to understand regional characteristics that have influenced this formation. As noted above, economic reforms implemented under Russia's transition, while initiated at the federal level, have differed markedly across regions: regional governments have had considerable discretion over the implementation of reform policies in their districts, and have pursued a wide range of policy packages. We exploit these differences in analyzing whether regional differences in reform policies can account for regional differences in growth, and conclude that to a considerable degree, they can. Specifically, we find that regions in which privatization has been initiated predominately by local governments rather than provincial and federal governments, and in which regional-government initiatives to gain control over their capital stock have been successful, have been most effective in attracting new enterprises. In turn, as Figures 1 and 2 illustrate, new-enterprise formation corresponds closely with economic growth.

Recent empirical work on transition in the Former Soviet Union and Eastern Europe has analyzed explanations for differences in economic growth observed across countries. Several studies have emphasized the importance of stabilization (Aslund, Boone and Johnson, 1996; de Melo, Denizer and Gelb, 1996; Fisher, Sahay and Gelb, 1996; Sachs and Warner, 1996; Sachs, 1997) and other liberalization 
policies (de Melo and Gelb, 1996; Selowsky and Martin, 1997). Others have emphasized pre-transition initial conditions (Blanchard and Kremer, 1997; de Melo, Denizer, Gelb and Tenev, 1997). Finally, Johnson, Kaufmann and Shleifer (1997) have emphasized the role of public finances and corruption.

This paper and recent work by Wamer (1999) are the only studies we know of that analyze reforms at the regional level. Warner's interest is in the relationship between the adoption of regional reform policies and voting patterns in Russia's December 1995 parliamentary elections. He finds regions that adopted relatively liberal reforms as of the autumn of 1995 tended to support pro-reform parties. This result is robust to conditioning on regional measures of urbanization, economic distress, poverty, educational levels, resource endowments, etc. To relate our results regarding the relationship between reforms and growth to Wamer's study (albeit indirectly), we find that regions that voted for the antireform candidate in the June 1996 national election tended to be reluctant in adopting economic reforms, and experienced relatively low levels of new-enterprise formation and economic growth.

The paper is organized as follows. We present an overview of our data in Section 2. In Section 2a we describe our measures of growth and new-enterprise formation; in Section $2 b$ we describe our policy variables; and in Section $2 \mathrm{c}$ we introduce our measures of regional initial conditions. In Section $2 \mathrm{~d}$ we summarize the observed correlation between our variables in both the full data set and the sub-sample that excludes the three "outlier" regions. The basic patterns are that growth and new-enterprise formation are closely correlated; and that the policy variables are relatively weakly correlated among themselves and with growth, but are closely correlated with new-enterprise formation.

We build on these patterns in Section 3 by estimating a baseline model in which economic growth is a function of initial conditions and new-enterprise formation. In tum, new-enterprise formation is modeled as a function of initial conditions and our policy variables; these include measures of privatization, price liberalization, control initiatives, and tax rates. Using the full data set, we find that increases in the extent of overall small-scale privatization, the share of privatization initiated at the local level, and regional control initiatives are all significantly associated with increases in new-enterprise formation, and thus with increases in economic growth. In Section 4, we analyze the robustness of these results along several dimensions. We examine the validity of the exclusion of policy variables from our growth regression; the validity of the exclusion of growth from our new-enterprise-formation regression; the impact of excluding the three outlier regions from our sample; and the impact of the use of alternative measures of growth and new-enterprise formation in the analysis. In general, we find the results obtained using our baseline structural model and our full data set to be robust. We conclude in Section 5 . 


\section{Data Description}

In order to measure regional income growth, new-enterprise formation, reform policies, and initial conditions, we have compiled a data set that includes regions located in all eleven of Russia's geographic territories. There are 89 regions in Russia, including 21 republics, six krays, 49 oblasts, one autonomous oblast, ten autonomous okrugs, and two federal cities (Moscow and St. Petersburg). Ideally, we would work with data from all 89 regions. However, some of the variables we wish to measure are reported only at the capital-city level, and thus are not necessarily representative of the region as a whole. To minimize this problem, we limit our sample to regions in which the capital city comprises at least 30 percent of the total regional population. ${ }^{2}$ There are 47 such regions in Russia. These regions, along with their capital cities and geographic territories, are reported in Table 1.

\section{2a. Growth and New-Enterprise Formation}

We use real per capita income data to measure growth in regional standards of living (GROWTH). Our baseline measure of GROWTH is the annualized average growth rate between 1993:IV and 1996:IV of regional per capita money income, deflated by a regional-level consumer price index. An alternative measure we consider is the growth in real per capita food income. This is the average annualized growth rate of per capita money income, deflated by the average cost of a basket of 19 basic food goods. ${ }^{3}$ The cost of the basket is measured using surveys conducted in capital cities. The only difference between the baseline and alternative measures of growth is in the deflators they employ: the baseline measure is constructed using a relatively broad measure of prices measured at the regional (as opposed to the capital-city) level. The correlation between these alternative measures of growth is 0.734 in the full sample, and 0.560 in the sub-sample that excludes the "outlier" regions (see Table 3 ).

Our baseline measure of new-enterprise formation (NEWENT) is the number of small legally registered private enterprises per thousand inhabitants as of January 1, 1996. This measure approximates

\footnotetext{
${ }^{2}$ Below the 30-percent cutoff, there are regions such as Vologda and Kemerovo in which capital cities have smaller populations than other cities in the region. There are also regions such as the Sakha Republic that have very low population densities and small urban sectors throughout the region. In either case, capital-city data are likely to be relatively uninformative about the region as a whole.

${ }^{3}$ Data on both measures of growth are reported on a monthly, quarterly and average annual basis in Goskomstat Rossii (1993; 1994b,c; 1995b,c; 1996a,b,c,d; 1997).

${ }^{4}$ Another standard-of-living measure available from the Russian statistical office (Goskomstat) is per capita regional-level money income, divided by the regional-level cost of a subsistence-goods basket. We view this measure as unreliable for the following reasons. Yelena Borisovna Frolova, chief of the standards-of-living division of Goskomstat, indicated to us in an interview that the components of the subsistence basket vary non-transparently across regions. Also, in interviews with Alastair McAuley, an expert on standards of living in transition economies, we learned that federal transfers to provinces increase as the subsistence basket becomes more expensive. Regional officials who collect data for constructing the cost of subsistence baskets thus have an incentive to overstate costs.
} 
the regional "stock" of private small enterprises, since regional governments typically require their enterprises to register on an annual basis. An alternative measure we employ is the number of workers employed in the firms included in our baseline measure per thousand employed workers as of January 1 , 1996 (the data source for both measures is Goskomstat Rossii, 1997). The correlation coefficient between these measures of new-enterprise formation is 0.912 in the full sample and 0.764 in the sub-sample (see Table 3). While employment ceilings that define small enterprises vary across industries, the typical small enterprise employs no more than 200 workers. These small private enterprises include privatized former state enterprises, spin-offs from privatized state enterprises, and startups. Legal startups and spinoffs began to appear in the Former Soviet Union in the late 1980s and rapidly expanded when Russia began instituting radical economic reforms in the early 1990s (Aslund, 1997). Thus, our NEWENT measures are intended to capture the accumulated regional "stock " of legal entrepreneurial activity.

\section{2b. Policy Variables}

In its quest to transform its economy from a socialist to a capitalist system, the federal government of Russia initiated a broad range of policy reforms. But while the federal government initiated these reforms, their implementation has largely been the responsibility of regional governments. As a result, there has been considerable variation in the mix of reforms adopted at the regional level. The policy variables we analyze attempt to quantify this regional variation.

An important component of the policy reforms adopted in Russia involves the privatization of state-owned enterprises (proponents of the adoption of this type of reform include Shleifer and Vishny, 1994; and Boycko, Shleifer and Vishny, 1995). We quantify regional privatization activity using two measures. The first - TPRIV - is taken from Lavrov (1996); this measure characterizes the overall extent of small-scale privatization within each region. Specifically, this measure ranks each region on the scale $[1,0.8,0.6,0.4,0.2]$ as the percentage of small previously state-owned firms that had become privatized as of July 1996 ranges over 95 percent, between 90 and 95 percent, between 80 and 90 percent, between 50 and 80 percent, and below 50 percent. The reason for basing this measure on the extent of small-scale privatization is that our interest is in quantifying regional attitudes toward reform: the privatization of small enterprises has generally been the responsibility of regional (provincial and local authorities), while large-scale privatization has been primarily the responsibility of the federal government.

To further quantify regional attitudes towards privatization, we augment TPRIV with a second measure of the decentralization of the privatization process (LPRIV). This measures the average share of all privatized enterprises - both small- and large-scale - between 1993 and 1995 that were previously under local-government jurisdictions, as opposed to provincial or federal jurisdictions (the source of this measure is Goskomstat Rossii 1994a; 1995a; 1996a). Typically, when TPRIV is large, so too is LPRIV 
(see Appendix Table A1, p. 27). For example, TPRIV is 1 in Saratov, indicating that more than 95 percent of previously state-run small enterprises had been privatized in that region by 1996 .

Correspondingly, LPRIV is 0.658 , indicating that of the enterprises privatized between 1993 and 1995 , 65.8 percent had previously fallen under the jurisdiction of the local government. However, there are several exceptions to this pattern. For example, the extent of small-scale privatization is rather limited in Murmansk (where TPRIV is 0.4 ), but the fraction of privatized firms formerly controlled by the local government of the capital city is quite high (LPRIV is 0.734). Similar exceptions occur in Kaliningrad, Bryansk, Chuvash, Kirov, Lipetsk and Tomsk. A notable exception of the opposite type is observed in Ryazan (TPRIV = 1, LPRIV = 0.357).

Another important component of the policy reforms adopted in Russia involves the liberalization of prices, which had largely been controlled by the state in the Former Soviet Union (early proponents of the adoption of rapid price liberalization include Boycko, 1992; Murphy, Shleifer and Vishny, 1992; and Osband, 1992). We measure the extent of regional price liberalization (PRICE) using a Goskmostat survey of a basket of 73 food goods; the survey was conducted in capital cities in October 1995 (see European Union 1996a,b). In the survey, each good was checked for the type of regulation it was subject to. The regulation types include the following: allocation by rationing and the issuance of coupons (most conservative); sales subject to price ceilings (medium regulation); prices regulated by direct controls such as subsidies and limitations on price mark-ups (light regulation); and no price controls (liberalized). The survey tallied points for the extent of price regulation on each product. We sorted these results and ranked each region on a uniform scale from most regulated (1/47) to most liberal (1). Regions that score high in our price measure also tend to feature high privatization measures (see Table Al). For example, Samara, Saratov and Moscow are among the most liberal regions with respect to PRICE, and also have TPRIV measures of 1 . However, once again there are exceptions. For example, Nizhni Novgorod and St. Petersburg feature TPRIV measures of 1 , but only moderate measures of PRICE (0.468 and 0.489); and Kostroma, Tomsk, Perm and Kamchatka feature opposite combinations of these measures.

A fourth policy variable we consider is the average regional tax rate (TAX). This is measured using budgetary data collected in 1994 and 1995 from the Russian Ministry of Finance (see Keen and McAuley, 1996). It is constructed by deducting federal transfers from overall regional-government revenue, then dividing the remainder by money income. A better measure would be based on marginal tax rates for enterprise activity within the region, but we lack the data to construct such a measure. Another caveat with our measure is that it does not include unreported payments to corrupt and cashstrapped governments; it also ignores payments to protection groups (for these measurements at the national level in transition economies, see Johnson, Kaufmann and Shleifer, 1997). 
A final aspect of Russia's reform we consider is the decentralization of power from the federal to regional governments. Theoretical and empirical work on decentralization argues that, in the absence of privatization, regional governments that have significant control over their capital stocks are better able to encourage new-enterprise formation (e.g., see Shleifer and Vishny, 1993; and Berkowitz and Li, 1999). In the case of Russia, under socialism, regional governments had little control over their capital stocks: major enterprises and infrastructure were under the jurisdiction of the federal government and its ministries. During transition, provincial and local governments have competed with each other, the federation, enterprise mangers, ministerial officials, and financial groups for control over major enterprises, which provide key sources of tax revenue, employment, and public goods and services. In Russia's somewhat chaotic decentralization efforts, federal governments, regulatory organs, and regional governments have often had overlapping claims to cash flows, outputs, and resources from the same enterprises. Since it is difficult for these agencies to coordinate policy, the resulting tax and regulatory system has in many regions become non-transparent and burdensome, thus retarding new-enterprise formation (Frye and Shleifer, 1997). In contrast, regional governments that gained substantial control over their capital stocks have a choice: they can use their power either to prey upon new enterprises, or develop a regulatory environment that encourages new-enterprise formation (Berkowitz and $\mathrm{Li}, 1999$ ).

We measure the extent of decentralization (CONTROL) using a survey of the share of the regional capital stock that regional governments own (see the European Union, 1996a). The remainder is owned by federal agencies, non-profit organizations, private companies (including foreign ones) and private citizens. By capital stock, we refer to buildings, equipment, machinery and social infrastructure. CONTROL ranks each region on the scale $[1,0.8,0.6,0.4,0.2]$ as the share of regional capital owned by the regional government as of January 1995 ranges over 40 percent, between 30 and 40 percent, between 20 and 30 percent, between 15 and 20 percent, and lower than 15 percent. Since the federation has less leverage over regions that control the bulk of their capital, CONTROL provides a proxy for a regional government's ability to conduct an independent tax policy. However, the proxy is imperfect: low values of CONTROL may reflect high levels of private (as opposed to federal) ownership, and thus does not necessarily imply an inability of the regional government to conduct an independent tax policy.

It is not surprising that regions that score high on CONTROL tend to rank poorly on small-scale privatization (the correlation between CONTROL and TPRIV is -0.303). For example, the Republics of Tatarstan, Kabardin Balkar, Mariy-El and North Osetia and the Tyumen oblast all rank highest in CONTROL; however, each of these regions is below average in TPRIV. Kamchatka oblast and the Adyegey Republic are the only other regions in the top rank for CONTROL, and both are roughly average for TPRIV. More notable is the relationship between CONTROL and the average regional tax rate (TAX). This is illustrated in Figure 3a, which plots TAX against CONTROL, and the fitted line obtained 
by regressing TAX on a constant and CONTROL. There is clearly a negative relationship between TAX and CONTROL: the correlation between the two variables is -0.321 . What is more interesting is that the variance in TAX from the predicted fit is highest for those regions ranking highest in CONTROL. This suggests that regional governments become less predatory as they acquire more control over their capital stock up to a certain point. In the highest CONTROL category, a dichotomy emerges: regional governments seem to provide a tax environment that is either conducive or hostile to new-enterprise formation. In particular, the Republics of Tatarstan (CONTROL = 1, TAX $=34.7$ percent) and Mariy-El $($ CONTROL $=1$, TAX $=28.8$ percent $)$ appear predatory. Figure $3 \mathrm{~b}$ eliminates these two "predators"; in this case, the correlation between TAX and CONTROL intensifies to -0.585 .

With the exception of TAX and CONTROL, the policy variables are constructed to have a theoretically positive relationship with new-enterprise formation. Regarding TAX, higher values of course reflect higher regional tax burdens, and therefore may have a negative relationship (for a theoretical analysis of this relationship, see Johnson, Kaufmann and Shleifer, 1997). Regarding CONTROL, the expected relationship is ambiguous. If CONTROL is a good proxy for the ability of a regional government to conduct an independent tax policy and the regional government is not predatory, we would expect the relationship to be positive. If instead higher values of CONTROL signal predatory governance, as seems to be true in Tatarstan and Mariy-El, the relationship could be negative.

\section{2c. Initial conditions}

Our primary focus is on the relationship between policy, new-enterprise formation and growth. However, in order to control for the influence of other relevant factors, we also consider three measures of regional initial conditions. The first is a measure of initial standards of living.

There is a large literature on the relationship between initial standards of living and growth. For example, Barro and Xavier Salai-i-Martin (1992) present evidence of convergence in standards of living across U.S. states. Regarding transition economies, Blanchard and Kremer (1997) make a theoretical argument and provide confirming evidence that the denser were inter-industry flow patterns under socialism, the more disorganization tended to occur during transition as state-sector enterprises were restructured and privatized, and thus the greater were resulting declines in output. de Melo, Denizer, Gelb and Tenev (1997) show that countries that had stronger traditions of market institutions prior to the advent of socialism experienced stronger growth performances during their transitions. Finally, Jefferson and Rawski (1994) and de Melo and Ofer (1999) show that regions within China and Russia with relatively high initial standards of living have tended to undertake relatively extensive economic reforms.

Our measure of initial regional standards of living (NITIAL) is nominal per capita income divided by the cost of the basket of 19 basic food goods in 1993:IV. While it would have been useful to 
report an earlier standard of living, our measure is based on the earliest available price data that encompass a broad regional consumption basket.

The second regional initial condition we consider is initial production potential (10), which is measured using data taken from Gaddy (1996), who reported labor shares employed in various industrial sectors and the defense industry within each region in 1985. We multiplied these shares by the industry's value added, net of labor costs (intermediate shadow-profit rate), and summed the resulting products to compute IO. These intermediate shadow-profit rates use world-market prices and Soviet input-output tables, and were computed by Senik-Leygonie and Hughes (1992). It is worth noting that the oil and gas industries have the highest value added in the industrial sectors, while food processing has the lowest (indeed, negative) value added. IO is meant to characterize the basic industrial structure of the region prior to transition: a high value indicates the regional presence of relatively competitive industries (e.g., oil and gas production). A priori, we expected this variable to be positively associated with GROWTH.

The final initial condition we consider is the regional importance of the defense industry (DEFENSE) prior to transition. This measure is taken from Gaddy (1996); it is the number of workers employed in the defense industry per thousand employed workers in the region in 1985. Gaddy argues that the defense industry should have a positive impact on growth because it attracted highly skilled workers and gave regions strong political connections with major power brokers in Moscow. We expected DEFENSE to have a positive relationship with GROWTH, given the relative stability of this industry in an otherwise turbulent economic environment.

\section{2d. Summary statistics}

Tables 2, 3, and Al summarize our data. Several aspects of Russia's inter-regional growth experience are evident in these tables. First, the overall growth record is poor. In the full sample, only seven of the 47 regions experienced positive real income growth over this period; in contrast, 19 had growth rates between -9.9 percent and -22 percent (Table 2). The growth rates obtained by deflating income by food prices are less dismal: 12 regions experienced positive growth according to this measure, and the average annual growth rate of -2.2 percent in this measure compares well with the average rate of -6.7 percent observed in the baseline measure. This difference in growth measures is consistent with the overall inflation record in Russia: services and non-food goods have generally become more expensive relative to food goods over this period.

Second, there is a strong relationship between growth and new-enterprise formation. This has been noted in the Introduction and Figures 1 and 2 for our baseline measures of these variables. Table 3 illustrates that, in the full sample, this relationship remains strong when we use food income and/or employment in new firms in measuring growth and new-enterprise formation. However, relationships are 
weaker in the sub-sample that excludes the three outlier regions: the correlation between real income growth and employment is 0.328 , the correlation between food-income growth and employment is 0.256 ; and the correlation between food-income growth and the number of new firms is only 0.025 .

Third, in general, the reform variables are quite weakly correlated amongst themselves (Table 3), and there is considerable inter-regional variability in the mix of adopted policies (Table Al). These features of the data prompt our observation that the regional governments included in our sample have implemented markedly different reform packages. For example, the Nizhni Novgorod oblast aggressively pursued privatization during this period (TPRIV $=1.0$ ), but had a mediocre record in relaxing price controls (PRICE $=0.468$ ); the opposite was true in the Tomsk oblast (TPRIV =0.4, PRICE $=0.957$ ). And while the Tatarstan Republic bargained aggressively with federal authorities to gain control over the capital stock within its territory (CONTROL $=1.0$ ), it moved slowly on price liberalization and privatization (PRICE $=0.234$, TPRIV $=0.4$ ). As a final example, the local governments in the Ryazan oblast played only a limited role in the extensive small-scale privatization observed there (TPRIV $=1$, LPRIV $=0.357$ ); in contrast, the local governments in the Saratov oblast actively participated in their extensive small-scale privatization (TPRIV $=1$, LPRIV $=0.658$ ).

The correlations in Table 3 also show that, except for LPRIV (and PRICE using our alternative measure of GROWTH), the relationship between the policy and growth is weak. For example, the Saratov oblast and the city of Moscow both implemented broad small-scale privatization and extensive price liberalization. However, Moscow had the most rapid growth in both real and food income, while Saratov had one of the worst growth records in either category. As a second example, both the Tyumen oblast and the Republic of Adyegey had the highest control over their regional capital stocks and very low tax burdens. However, while Tyumen experienced positive growth in both real income and food income, the Adyegey Republic experienced one of the worst growth records in our sample.

Finally, there is a stronger relationship between our policy measures and new-enterprise formation. As previously noted, a priori, we would expect to observe a positive relationship between TPRIV, LPRIV and PRICE and NEWENT; a negative relationship between TAX and NEWENT; and a positive relationship between CONTROL and NEWENT for regions where the regional government is not predatory. The distribution of new firms per thousand inhabitants in our sample is skewed upwards (with median 3.88 and average 4.39), and there are 15 above-average regions in our sample. Of these regions, 11 out of 15 are above average in at least three out of the five policy measures, and three (Novgorod, Kamchatka and Magadan) are above average in all five policy variables.

Having summarized general patterns evident in the data, we now turn to a more formal regression analysis. In the next section we present a set of baseline results. We then characterize the robustness of these results to a variety of considerations. 


\section{Baseline Estimates}

The clearest pattern of results we obtain emerges from OLS estimates of the following model:

(1) NEWENT $=\gamma_{0}+\gamma_{1}$ INITIAL $+\gamma_{2}$ TPRIV $+\gamma_{3}$ LPRIV $+\gamma_{4}$ PRICE $+\gamma_{5}$ CONTROL $+\gamma_{6}$ TAX $+e$

(2) GROWTH $=\beta_{0}+\beta_{1}$ INITIAL $+\beta_{2}$ IO $+\beta_{3}$ DEFENSE $+\beta_{4}$ NEWENT $+u$

The specification of this model resulted from an extensive diagnostics analysis, and the estimates we obtained were subjected to an extensive set of robustness checks. In this section, we will focus on OLS estimates of (1) and (2) obtained using the full data set, and our baseline measures of GROWTH and NEWENT; these are presented in Table 4. The robustness of these estimates is discussed in Section 4.

Regarding the NEWENT regression, the fit of the model is impressive: we obtain an $R^{2}$ statistic of 0.519 , and each of the policy variables has a coefficient of the expected sign. The coefficients on PRICE and TAX are statistically insignificant, but the remaining coefficients are significant at the 5percent level. They are also significant quantitatively. Specifically, the coefficient estimates on TPRIV, LPRIV and CONTROL indicate that, everything else equal, a one-standard-deviation increase in these variables corresponds with an additional $1.04,0.67$ and 0.82 new firms per 1,000 inhabitants in the region, respectively.

At first glance, the insignificance of PRICE in the NEWENT regression is surprising, since the presence of price controls is suggestive of a hostile environment for enterprises. However, since regulators can typically administer prices in state and former-state enterprises, but have limited control over prices for enterprises operating outside the state sector, this result is perhaps not surprising after all (Berkowitz, DeJong and Husted, 1998). The insignificance of TAX is surprising, since Russian entrepreneurs frequently complain that the tax system represents their biggest impediment to success (Hendley et al., 1997). However, much of this burden is in the form of unreported payments demanded by cash-strapped or corrupt government officials (Frye and Shleifer, 1997); the fact that these payments are not captured in our official budgetary data may account for the insignificance of our measure.

As noted above, to the extent that CONTROL is a good proxy for a regional government's ability to conduct an independent tax policy, the significance of this variable supports the theoretical work of Shleifer and Vishny (1993) and Berkowitz and $\mathrm{Li}$ (1999). When decentralization results in a de facto system in which different levels of government have overlapping control over enterprises, predatory behavior among competing tax authorities can result, thus retarding the entry and development of new legal enterprises. Another possible reason for the significance of CONTROL is that a substantial component of controlled capital stocks is social infrastructure (which includes roads, sewers, bridges, 
ports and communications facilities). A regional government that enjoys well-defined control rights has an incentive to maintain or improve its social infrastructure: doing so enables enterprises to operate more efficiently, thus strengthening its regional tax base. This incentive is weakened as the number of agencies with overlapping control rights increases, since the incremental tax revenue from investment in social infrastructure is typically shared in an uncoordinated fashion among competing agencies. Unfortunately, there is no way to determine from the data the proportion of the capital stock that is comprised by social infrastructure in our measure of CONTROL (the other significant component of our measure is state enterprises, which have no obvious positive benefits for NEWENT). Despite the impurity of our measure, it nevertheless has impressive explanatory power.

The privatization variable TPRIV has obvious direct implications for NEWENT; its significance is certainly not surprising. Finally, the significance of LPRIV indicates a prominent role for localgovernment privatization initiatives in spurring new-enterprise formation.

Regarding the GROWTH regression, the fit of the model is also quite good: here, we obtain an $\mathrm{R}^{2}$ statistic of 0.47 . Surprisingly, neither INITIAL nor IO have statistically significant coefficients; however, the coefficients on DEFENSE and NEWENT are significant both statistically and quantitatively. Our estimates indicate that a one-standard-deviation increase in DEFENSE (an additional 13.11 workers per thousand employed in the defense industry) corresponds with an additional annual growth rate of 1.62 percent. And remarkably, a one-standard-deviation increase in NEWENT (an additional 2.66 new firms per thousand inhabitants) corresponds with an additional annual growth rate of 5 percent.

\section{Robustness}

The robustness of the baseline estimates presented in Table 4 was evaluated along several dimensions. These fall under four general categories: sensitivity to the exclusion of the three "outlier" regions; sensitivity to the use of the alternative measures of GROWTH and NEWENT; the impact of potential simultaneity between GROWTH and NEWENT; and the specific structural specification of (1) and (2) - most notably, the restriction of GROWTH from the NEWENT equation, and the restriction of NEWENT from the GROWTH equation.

Given the first two categories, we worked with four measures of both GROWTH and NEWENT in each stage of our analysis: the baseline and alternative measures in both the full data set and the subsample obtained by excluding the "outlier" regions. OLS estimates of (1) obtained using the four measures of NEWENT are presented in Table 5. Several comparisons with the estimates in Table 4 (reprinted in the first row of Table 5) are notable. First, the statistical significance of TPRIV, LPRIV and CONTROL is robust to the exclusion of the "outlier" regions, but the quantitative significance of each variable is roughly cut in half (as is the $R^{2}$ statistic). However, of these variables, only TPRIV remains 
statistically significant when the alternative measure of NEWENT is used (employment in new firms per 1,000 inhabitants). Given the high correlation between the two NEWENT measures, this latter result is surprising. Evidently, these policy variables correspond relatively closely with the number of new firms in each region, but less closely with employment levels in these new firms. PRICE and TAX are insignificant in all four regressions, and INITLAL is significant using both measures of NEWENT, but only in the full data set.

Since both GROWTH and NEWENT appear in (2), there are eight possible combinations of these variables to consider in estimating this equation. In addition, their joint inclusion in (2) raises the possibility that OLS estimates of (2) are tainted by simultaneity bias. Thus, we estimated this equation using both OLS and two-stage least squares (2SLS). In generating 2SLS estimates, we first regressed NEWENT on levels and squares of each of the variables included in (1), as well as IO and DEFENSE, and then used the instrumented version of NEWENT in estimating (2). So, we estimated (2) using eight combinations of GROWTH and NEWENT and two estimation procedures, yielding 16 sets of estimates. These are reported in Table 6.

Each row of Table 6 reports OLS and 2SLS estimates of each coefficient side-by-side; the baseline results reported in Table 4 are reprinted in the first row of Table 6 for comparison. In the full data set, each of the eight estimates of the coefficient on NEWENT is positive and significant; the estimates range from 1.47 to 1.951 (the baseline estimate is 1.882 ). The significance of the remaining variables is sensitive to the measure of GROWTH we employ: the coefficient on DEFENSE is positive and significant only in using the baseline measure; and the coefficients on INITIAL and IO are significant only in using the alternative measure. The coefficients on INITIAL indicate that in terms of food purchasing power, Russia's regions have shown a tendency towards convergence during this period.

The pattern of findings regarding the coefficients on DEFENSE and INITIAL carry over to the sub-sample: the coefficients on DEFENSE are positive and significant using the baseline measure of GROWTH; and the coefficients on INITIAL are negative and significant using the alternative measure of GROWTH. The coefficients on IO are always insignificant in the sub-sample. Finally, the coefficients on NEWENT are positive and significant in four out of eight cases. Using the baseline measures of GROWTH and NEWENT, the coefficient estimates (1.673 using OLS, 1.714 using 2SLS) are similar to their full-sample counterparts; in the remaining cases the coefficient estimates are lower by approximately one standard deviation on average.

Given concems regarding potential simultaneity, either due to feedback or the omission of variables that have a joint impact on GROWTH and NEWENT, a comparison of the OLS and 2SLS estimates is of interest. We tested the equivalence of these estimates formally for all eight combinations of GROWTH and NEWENT measures using Hausman's (1978) specification test, and failed to reject the 
null hypothesis of equivalence in each case. For example, we obtained a test statistic of 0.63 using the full sample and the baseline measures of GROWTH and NEWENT; the asymptotic distribution of this statistic is $\chi^{2}(5)$, implying a $p$ value of 0.98 . The closest we came to rejecting the null was in the subsample, using the alternative measures of each variable. The test statistic we obtained in this case is 1.75 , which has a $p$ value of 0.88 . Thus we failed to find evidence of simultaneity in the data.

Another concern is with the exclusion restrictions embodied in (1) and (2). Two restrictions are of particular interest. The first involves the exclusion of the policy variables in accounting for GROWTH in (2). We tested this restriction in two ways. First, using OLS, we regressed GROWTH on the entire set of variables analyzed in this study, and tested the joint exclusion of the policy variables using an $F$ test. The results of this test, and the coefficient on NEWENT estimated using this model, are reported in Table 7 for all combinations of our measures of GROWTH and NEWENT. The exclusion restrictions are not rejected in the four regressions that involve the baseline measure of GROWTH, but are rejected using the alternative measure in three of the four cases; PRICE, TPRIV and CONTROL are all significant in accounting for this measure of GROWTH. However, the coefficient estimates obtained for NEWENT in this model continue to reflect the importance of NEWENT in accounting for GROWTH: the coefficient on NEWENT is significant in seven of the eight cases, and the coefficient estimates obtained using this model are uniformly higher than those obtained using (2) (reported in Table 6).

Second, we conducted a sequence of exclusion-restriction tests using 2SLS. This involved modifying (2) to include all but one of the policy variables, with the remaining variable serving as the lone instrument for NEWENT in (1). We estimated each of the five possible versions of this modification of the model (one for each policy variable), and tested the joint exclusion of the policy variables included in the GROWTH equation. The results of this exercise mirror those reported in Table 7, thus we do not report them in detail here.

The second restriction of interest is the exclusion of GROWTH from the NEWENT equation (1). To test this restriction, we estimated a version of (1) that was modified to include GROWTH as an explanatory variable. Using 10 and DEFENSE as instruments for GROWTH, we estimated this modification of (1) using 2SLS. The estimates of the coefficient on GROWTH we obtained are reported in Table 7; they are statistically insignificant in all eight cases.

Taken together, our results broadly support the importance of new-enterprise formation in generating economic growth in Russia. Policy reforms that appear particularly important in generating new-enterprise formation include regional-government privatization initiatives, and regional-government initiatives to gain control over capital stocks. ${ }^{5}$

\footnotetext{
${ }^{5}$ In a related robustness check, we explored the impact of excluding the seemingly predatory regional governments in the Tatarstan and Mariy-El Republics in measuring CONTROL. As Figure 3 illustrates, excluding
} 
We conclude by noting that our findings complement and extend Warner's (1999) work on the relationship between reform and voting behavior at the regional level. Warner shows that reform-oriented regions tended to support pro-reform parties in Russia's December 1995 parliamentary elections. In Table 8, we report the relationship between voting patterns, policy, new-enterprise formation and growth in our data sample. To measure voting patterns, we divided our sample into two categories: Non-Red-Belt and Red-Belt Regions. In Non-Red-Belt regions, the majority of votes cast in both rounds of the June 1996 presidential elections were cast for the pro-reform incumbent (Yeltsin); in Red-Belt regions, majorities voted for the ant-reform opposition (Zyuganov) in the second (and decisive) round of the election. Consistent with Warner's findings, Red-Belt regions have relatively low measures of NEWENT, LPRIV and PRICE; differences between these measures are all statistically significant at the five-percent level. Moreover, Red-Belt regions grew at slower rates on average than Non-Red Belt regions $(-10.16$ percent versus -3.97 percent in our baseline measure, a difference that is significant at the one-percent level). ${ }^{6}$

\section{Conclusion}

We have explored the relationship between economic policy reforms, new-enterprise formation, and economic growth in Post-Soviet Russia. Most notably, we have found that local-government privatization initiatives and regional-government initiatives to gain control over their capital stocks exhibit strong positive relationships with the formation of new enterprises, which in turm exhibits a strong positive relationship with economic growth.

At the aggregate level, Russia has experienced a difficult transition to a market-oriented economy. Despite this, there are clearly regions within Russia that have experienced economic success during transition. Our results suggest that a more widespread pursuit of privatization and control initiatives at the regional-government level could hold the key to a brighter economic future throughout Russia.

these regions strengthens the negative relationship between CONTROL and TAX. It also strengthens the relationship between CONTROL and NEWENT. For example, using the baseline measure of NEWENT, this exclusion raises the coefficient estimated in (1) from 3.258 to 3.958 , and the coefficient remains statistically significant at the five-percent level.

${ }^{6}$ For a further discussion of the relationship between the Red Belt, policy, growth and inter-regional price dispersion, see Berkowitz and DeJong (1998, and forthcoming). 


\section{REFERENCES}

Aslund, Anders, Peter Boone and Simon Johnson (1996), "How to Stablilize: Lessons from PostCommunist Countries", Brookings Papers on Economic Activity 1: 217-313.

Aslund, Anders (1997), "Observations on the Development of Small Private Enterprises in Russia", PostSoviet Geography and Economics 38: 191-206.

Barro, Robert J. and Xavier Salai-I-Martin (1992), "Convergence", Journal of Political Economy 100: 223-51.

Berkowitz, Daniel, David N. DeJong and Steven Husted (1997), "Quantifying Price Liberalization in Russia," Journal of Comparative Economics 26: 735-60.

Berkowitz, Daniel and David N. DeJong (1998), "Russia's Internal Border," Department of Economics, University of Pittsburgh, mimeo and forthcoming in Regional Science and Urban Economics.

Berkowitz, Daniel, and Wei Li (1999), "Decentralization in Transition Economies: A Tragedy of the Commons?" William Davidson Institute Working Paper, University of Michigan, September.

Blanchard, Olivier (1997), The Economics of Post-Communist Transition. Oxford University Press: London.

Blanchard, Olivier., and Michael Kremer (1997), "Disorganization", Quarterly Journal of Economics 112: 1091-1126.

Boycko, Maxim (1992), "When Higher Incomes Reduce Welfare: Queues, Labor Supply, and Macro Equilibrium in Socialist Economies", Quarterly Journal of Economics 107: 907-20.

Boycko, Maxim, Andrei Shleifer and Robert Vishny (1995), Privatizing Russia. The MIT Press:

Cambridge, Massachusetts and London, England.

de Melo, Martha and Alan Gelb, (1996) "A Comparative Analysis of Twenty-eight Transition Economies in Europe and Asia", Post-Soviet Geography and Economics 37: 265-85.

de Melo, Martha, Cevdet Denizer and Alan Gelb (1996), "Patterns of Transition from Plan to Market", World Bank Economic Review, September 10(3): 397-424.

de Melo, Martha, Cevdet Denizer, Alan Gelb and Stoyan Tenev (1997), "Circumstance and Choice: The Role of Initial Conditions and Policies in Transition Economies", unpublished paper, the World Bank, August.

de Melo, Martha and Gur Ofer (1999), "The Russian City in Transition: The First Five Years in Ten Volga City Capitals," mimeo, Development Research Group, the World Bank, April.

European Union's TACIS Program (1996a), Analysis of Tendencies of Russia's Regions: Development in 1992-1995. Contract BIS/95/321/057, Moscow, March.

European Union's TACIS Program (1996b), Analysis of Tendencies of Russia's Regions' Development in 1992-1995: Typology of regions, conclusions and recommendations. BIS/95/321/057, Moscow, September. 
Fisher, Stanley, Ratna Sahay, and Alan Gelb (1996), "Economies in Transition: The Beginnings of Growth", American Economic Review, May (Papers and Proceedings), 86(2): 229-33.

Frye, Timothy, and Andrei Shleifer (1997), "The Invisible Hand and the Grabbing Hand," American Economic Review, May (Papers and Proceedings), 87(2): 354-58.

Gaddy, Clifford (1996), The Price of the Past, Brookings Institute: Washington, DC.

Goskomstat Rossii (1994a, 1995a, 1996a), Rossiyskiy Statisticheskii Yezhegodnik. Goskomstat Rossii: Moscow.

Goskomstat Rossii (1993, 1994b, 1995b, 1997), Sotsial'noe Ekonomicheskoye Polozhenie Rossii. Goskomstat Rossii: Moscow.

Goskomstat Rossii (1994c, 1995c, 1996c), Tseny v Rossii. Goskomstat Rossii: Moscow.

Goskomstat Rossii (1996d), Uroven' Zhizni Nasileniya Rossii. Goskomstat Rossii: Moscow.

Hausman, Jerry (1978), "Specification Tests in Econometrics", Econometrica 46: 1251-1272.

Hendley, Kathryn, Barry W. Ickes, Peter Murrell and Randi Ryterman (1997), "Observations on the Use of Law by Russian Enterprises", Post-Soviet Affairs, 13(1): 19-41.

Jefferson. Gary H. and Thomas G. Rawski (1994), "How Industrial Reform Worked in China: The Role of Innovation, Competition and Property Rights." In Proceedings of the World Bank Annual Conference on Development Economics 1994: World Bank: Washington, DC, pp. 129-156.

Johnson, Simon, Daniel Kaufmann and Andrei Shleifer (1997), "The Unofficial Economy in Transition", Brookings Papers on Economic Activity, 2: 159-240.

Keen, Michael and Alastair McAuley (1996), Fiscal Policy and Fiscal Federalism in Russia, Final Report, Prepared for the DGXXI of the European Commission under Contract XXI/95/CB-2028, October.

Kornai, Janos (1990), The Road to a Free Economy. Shifting from a Socialist System: The Example of Hungary. W.W. Norton: New York.

Kornai, Janos (1992), The Socialist System: The Political Economy of Communism. Princeton University Press: Princeton.

Lavrov, Alexei, (1996), Economic Policies of the Subjects of the Russian Federation, World Bank (Moscow) report.

Murphy, Kevin, Andrei Shleifer, and Robert Vishny (1992), "The Transition to a Market Economy: Pitfalls of Partial Reform", Quarterly Journal of Economics 107: 889-906.

Osband, Kent (1992), "Economic Crisis in a Shortage Economy," Journal of Political Economy 100: 67390. 
Sachs, Jeffrey D. and Andrew M. Wamer (1996), "Achieving Rapid Growth in The Transition Economies of Central Europe", Stockholm Institute of East European Economics, Working Paper 116, November.

Sachs, Jeffrey D. (1997), "The Transition at Mid Decade", American Economic Review, May Papers and Proceedings), 86(2): 128-33.

Selowsky, Marcelo and Ricardo Martin (1997), "Policy Performance and Output Growth in Transition Economies", American Economic Review, May (Papers and Proceedings), 87(2): 349-53.

Senik-Leygonie, Claudia and Gordon Hughes (1992), Industrial Profitability and Trade Among the Former Soviet Republics, Economic Policy (15), October: 354-386.

Shleifer, Andrei and Robert Vishny (1993), "Corruption", Quarterly Journal of Economics, 108: 599 618.

Warner, Andrew (1999), "Is Economic Reform Popular at the Polls: Russia 1995?" revised mimeo dated May 1997, Harvard Institute for International Development and Center for International Development, Harvard University. 
Table 1: Regions Included in Data Set

\begin{tabular}{|c|c|c|}
\hline Capital City & Province & Georgraphic Territory \\
\hline Petrozavodsk & Karelian Republic & Northern \\
\hline Murmansk & Murmansk oblast & \\
\hline St. Petersburg & & Northwestern \\
\hline Kaliningrad & Kaliningrad oblast & \\
\hline Novgorod & Novgorod oblast & \\
\hline Bryansk & Bryansk oblast & Central \\
\hline Ivarovo & Ivanovo oblast & \\
\hline Kaluga & Kaluga oblast & \\
\hline Kostroma & Kostroma oblast & \\
\hline Moscow & & \\
\hline Oryol & Oryol oblast & \\
\hline Ryazan & Ryazan oblast & \\
\hline Smolensk & Smolensk oblast & \\
\hline Tula & Tula oblast & \\
\hline Yaroslavl & Yaroslavl oblast & \\
\hline Yoshkar & Mariy-El Republic & Volga-Vyatka \\
\hline Saransk & Mordovian Republic & \\
\hline Cheboksary & Chuvash Republic & \\
\hline Kirov & Kirov oblast & \\
\hline Nizhniy Novgorod & Nizhniy Novgorod oblast & \\
\hline Voronezh & Voronezh oblast & Central Black-Earth \\
\hline Kursk & Kursk oblast & \\
\hline Lipetsk & Lipetsk oblast & \\
\hline Kazan & Tatarstan Republic & Volga Region \\
\hline Astrakhan & Astrakhan oblast & \\
\hline Volgograd & Volgograd oblast & \\
\hline Penza & Penza oblast & \\
\hline Samara & Samara oblast & \\
\hline Saratov & Saratov oblast & \\
\hline Ulyanovsk & Ulyanovsk oblast & \\
\hline Maykop & Adygey Republic & North Caucasus \\
\hline Nalchik & Kabardin-Balkar Republic & $\cdot$ \\
\hline Vladikavkaz & North Osetian Republic & \\
\hline Izhevsk & Udmurt Republic & Urals \\
\hline Kurgan & Kurgan oblast & \\
\hline Perm & Perm oblast & \\
\hline Yekaterinburg & Sverdlovsk & \\
\hline Chelyabinsk & Chelyabinsk oblast & \\
\hline Novosibirsk & Novosibirsk oblast & Western Siberia \\
\hline Omsk & Omsk oblast & \\
\hline $\begin{array}{l}\text { Tomsk } \\
\text { Tyumen }\end{array}$ & Tomsk oblast & \\
\hline $\begin{array}{l}\text { Tyumen } \\
\text { Ulan Ude }\end{array}$ & Tyumen oblast & Eastem Siberia \\
\hline Vladivostock & Primorskiy Kray & Far East \\
\hline Khabarovsk & Khabarovsk Kray & \\
\hline Petropavlovsk & Kamchatka oblast & \\
\hline Magadan & Magadan oblast & \\
\hline
\end{tabular}


Table 2: Growth and New-Enterprise Formation

\begin{tabular}{|c|c|c|c|c|}
\hline \multirow[b]{2}{*}{ Region } & \multicolumn{2}{|c|}{ GROWTH } & \multicolumn{2}{|c|}{ NEWENT } \\
\hline & Real Income & Food Income & Firms & Employment \\
\hline Karelian & $-11.5 \%$ & $-3.7 \%$ & 4.59 & 9.20 \\
\hline Murmansk & $-17.2 \%$ & $-6.5 \%$ & 4.78 & 7.90 \\
\hline St. Petersburg & $7.9 \%$ & $12.3 \%$ & 12.39 & 16.70 \\
\hline Kaliningrad & $-8.1 \%$ & $-3.5 \%$ & 4.08 & 7.10 \\
\hline Novgorod & $6.6 \%$ & $2.7 \%$ & 4.45 & 11.60 \\
\hline Bryansk & $-14.7 \%$ & $-6.3 \%$ & 2.98 & 8.00 \\
\hline Ivanovo & $-11.4 \%$ & $-0.9 \%$ & 3.96 & 7.50 \\
\hline Kaluga & $-13.4 \%$ & $-4.5 \%$ & 5.76 & 9.10 \\
\hline Kostroma & $-10.3 \%$ & $-2.9 \%$ & 3.25 & 10.00 \\
\hline Moscow & $17.3 \%$ & $21.9 \%$ & 16.79 & 20.60 \\
\hline Oryol & $-15.9 \%$ & $-13.0 \%$ & 2.52 & 5.60 \\
\hline Ryazan & $-12.2 \%$ & $-5.3 \%$ & 3.69 & 7.40 \\
\hline Smolensk & $-1.8 \%$ & $0.8 \%$ & 2.48 & 9.50 \\
\hline Tula & $-10.0 \%$ & $-4.7 \%$ & 3.48 & 7.60 \\
\hline Yaroslavl & $-5.5 \%$ & $-2.3 \%$ & 4.90 & 9.80 \\
\hline Mariy-El & $-22.0 \%$ & $-12.7 \%$ & 2.09 & 5.90 \\
\hline Mordovian & $-6.2 \%$ & $-1.4 \%$ & 1.88 & 4.20 \\
\hline Chuvash & $-9.8 \%$ & $-4.8 \%$ & 3.08 & 6.30 \\
\hline Kirov & $-3.7 \%$ & $-0.8 \%$ & 1.96 & 5.90 \\
\hline Nizhniy Novgorod & $-9.8 \%$ & $-5.8 \%$ & 2.38 & 5.80 \\
\hline Voronezh & $-3.6 \%$ & $-0.2 \%$ & 3.08 & 6.70 \\
\hline Kursk & $-16.0 \%$ & $-6.7 \%$ & 1.71 & 6.30 \\
\hline Lipetsk & $-6.2 \%$ & $-3.1 \%$ & 2.40 & 6.00 \\
\hline Tatarstan & $-2.8 \%$ & $-5.9 \%$ & 4.22 & 5.80 \\
\hline Astrakhan & $-11.0 \%$ & $-2.9 \%$ & 4.21 & 11.20 \\
\hline Volgograd & $0.2 \%$ & $-6.2 \%$ & 6.14 & 10.60 \\
\hline Penza & $-12.4 \%$ & $-2.9 \%$ & 3.90 & 7.30 \\
\hline Samara & $-2.0 \%$ & $-0.7 \%$ & 4.74 & 9.90 \\
\hline Saratov & $-13.0 \%$ & $-8.9 \%$ & 3.80 & 7.90 \\
\hline Ulyanovsk & $-5.2 \%$ & $-8.7 \%$ & 2.55 & 5.30 \\
\hline Adygey & $-16.5 \%$ & $-4.1 \%$ & 4.00 & 9.60 \\
\hline Kabardin Balkar & $-3.7 \%$ & $-7.0 \%$ & 4.08 & 7.40 \\
\hline North Osetian & $-8.7 \%$ & $4.2 \%$ & 2.57 & 5.70 \\
\hline Udmurt & $-0.3 \%$ & $4.2 \%$ & 3.73 & 7.70 \\
\hline Kurgan & $-19.6 \%$ & $-2.9 \%$ & 2.79 & 6.60 \\
\hline Perm & $2.3 \%$ & $6.5 \%$ & 3.43 & 7.90 \\
\hline Sverdlovsk & $-1.0 \%$ & $-3.9 \%$ & 5.09 & 8.10 \\
\hline Chelyabinsk & $1.9 \%$ & $0.8 \%$ & 3.26 & 8.70 \\
\hline Novosibirsk & $-1.0 \%$ & $9.5 \%$ & 5.21 & 10.90 \\
\hline Omsk & $-3.7 \%$ & $-3.5 \%$ & 3.86 & 8.00 \\
\hline Tomsk & $-8.5 \%$ & $1.8 \%$ & 4.17 & 9.40 \\
\hline Tyumen & $1.9 \%$ & $4.0 \%$ & 9.35 & 13.10 \\
\hline Buryat & $-14.0 \%$ & $-8.1 \%$ & 3.91 & 6.90 \\
\hline Primorskiy Kray & $-5.2 \%$ & $2.5 \%$ & 5.02 & 9.50 \\
\hline Khabarovsk & $-7.9 \%$ & $-1.9 \%$ & 3.72 & 7.40 \\
\hline Kamchatka & $-5.4 \%$ & $-6.3 \%$ & 6.95 & 12.30 \\
\hline Magadan & $-3.2 \%$ & $-9.4 \%$ & 7.18 & 11.10 \\
\hline Average & $-6.7 \%$ & $-2.2 \%$ & 4.39 & 8.57 \\
\hline Median & $-6.2 \%$ & $-3.1 \%$ & 3.88 & 7.90 \\
\hline Standard deviation & $7.6 \%$ & $6.3 \%$ & 2.66 & 2.96 \\
\hline Minimum & $-22.0 \%$ & $-13.0 \%$ & 1.71 & 4.20 \\
\hline Maximum & $17.3 \%$ & $21.9 \%$ & 16.79 & 20.60 \\
\hline
\end{tabular}




\section{Table 3: Correlation Patterns}

\section{Full Data Set}

$\begin{array}{llllllllll}\text { Variable } & \text { G0 } & \text { Gl } & \text { S0 } & \text { SI } & \text { INI. IO } & \text { DEF. } & \text { TP. } & \text { LP. } & \text { PR. CON. TAX }\end{array}$

$\begin{array}{lllllllllllllll}\text { GO } & 1.00 & & & & & & & & & & & & \\ \text { Gl } & 0.734 & 1.00 & & & & & & & & & \\ \text { S0 } & 0.628 & 0.623 & 1.00 & & & & & & & & \\ \text { S1 } & 0.626 & 0.655 & 0.912 & 1.00 & & & & & & & \\ \text { INITIAL } & 0.234 & 0.021 & 0.467 & 0.338 & 1.00 & & & & & & \\ \text { IO } & 0.104 & 0.119 & -0.085 & -0.144 & 0.017 & 1.00 & & & & & \\ \text { DEFENSE } & 0.242 & 0.138 & -0.004 & -0.026 & -0.133 & 0.182 & 1.00 & & & & \\ \text { TPRIV } & 0.166 & 0.236 & 0.379 & 0.399 & -0.025 & 0.079 & 0.236 & 1.00 & & & & \\ \text { LPRIV } & 0.338 & 0.307 & 0.323 & 0.311 & 0.059 & -0.060 & -0.006 & 0.254 & 1.00 & & & \\ \text { PRICE } & 0.167 & 0.402 & 0.278 & 0.354 & -0.039 & -0.167 & -0.113 & 0.285 & 0.252 & 1.00 & & \\ \text { CONTROL } & 0.001 & -0.068 & 0.234 & 0.122 & 0.229 & -0.242 & -0.078 & -0.303 & -0.243 & 0.040 & 1.00 & \\ \text { TAX } & 0.007 & -0.122 & -0.245 & -0.291 & -0.238 & 0.135 & 0.246 & 0.005 & 0.036 & -0.252 & -0.321 & 1.00\end{array}$

Subset with Outliers Removed

$\begin{array}{llllllllll}\text { Variable } & \text { G0 } & \text { Gl } & \text { S0 } & \text { S1 } & \text { INI. IO } & \text { DEF. } & \text { TP. } & \text { LP. } & \text { PR. CON. TAX }\end{array}$

$\begin{array}{lrllllllllllll}\text { G0 } & 1.00 & & & & & & & & & & & & \\ \text { G1 } & 0.560 & 1.00 & & & & & & & & & \\ \text { S0 } & 0.281 & 0.025 & 1.00 & & & & & & & & \\ \text { S1 } & 0.328 & 0.256 & 0.764 & 1.00 & & & & & & & \\ \text { INITIAL } & -0.089 & -0.570 & 0.105 & -0.069 & 1.00 & & & & & & \\ \text { IO } & 0.063 & 0.086 & -0.366 & -0.345 & -0.101 & 1.00 & & & & & \\ \text { DEFENSE } & 0.306 & 0.187 & -0.001 & -0.043 & -0.063 & 0.199 & 1.00 & & & & \\ \text { TPRIV } & -0.025 & 0.011 & 0.247 & 0.266 & -0.079 & 0.076 & 0.218 & 1.00 & & & \\ \text { LPRIV } & 0.250 & 0.181 & 0.246 & 0.200 & 0.039 & -0.069 & -0.030 & 0.159 & 1.00 & & \\ \text { PRICE } & 0.045 & 0.357 & 0.185 & 0.305 & -0.265 & -0.196 & -0.103 & 0.258 & 0.208 & 1.00 & \\ \text { CONTROL } & -0.131 & -0.257 & 0.167 & -0.028 & 0.088 & -0.294 & -0.059 & -0.363 & -0.263 & 0.015 & 1.00 \\ \text { TAX } & 0.196 & 0.028 & -0.083 & -0.202 & 0.101 & 0.210 & 0.211 & -0.010 & 0.031 & -0.215 & -0.245 & 1.00\end{array}$

Note: G0 refers to growth in real income, G1 to growth in food income, S0 to new enterprises, S1 to employment in new enterprises. 
Table 4: OLS Estimates of Baseline Model

Dependent Variable: NEWENT $\quad R^{2}: 0.519 \quad \bar{R}^{2}: 0.447$

\begin{tabular}{cccc}
\hline Explanatory Variable & Coefficient & t statistic & p value \\
\hline CONSTANT & -6.593 & -2.330 & 0.025 \\
INITIAL & 1.284 & 3.305 & 0.002 \\
TPRIV & 4.458 & 3.203 & 0.003 \\
LPRIV & 5.294 & 2.120 & 0.040 \\
PRICE & 0.864 & 0.769 & 0.446 \\
CONTROL & 3.258 & 2.427 & 0.020 \\
TAX & -0.023 & -0.336 & 0.739 \\
\hline
\end{tabular}

Dependent Variable: GROWTH $\quad R^{2}: 0.470 \quad \bar{R}^{2}: 0.419$

\begin{tabular}{cccc}
\hline Explanatory Variable & Coefficient & $t$ statistic & p value \\
\hline CONSTANT & -17.175 & -4.713 & 0.000 \\
INITIAL & -0.463 & -0.379 & 0.707 \\
IO & 0.063 & 1.054 & 0.298 \\
DEFENSE & 0.124 & 1.863 & 0.069 \\
NEWENTS & 1.882 & 5.164 & 0.000 \\
\hline
\end{tabular}


Table 5: Robustness Check for NEWENT Regression

\begin{tabular}{|c|c|c|c|c|c|c|c|}
\hline NEWENT Measure & $\mathbf{R}^{2}$ & \multicolumn{6}{|c|}{ Explanatory Variable } \\
\hline Employment, Full Sample & 0.419 & $\begin{array}{l}1.004 \\
(2.111)^{* *}\end{array}$ & $\begin{array}{c}4.524 \\
(2.656)^{* *}\end{array}$ & $\begin{array}{c}4.815 \\
(1.576)\end{array}$ & $\begin{array}{c}1.716 \\
(1.248)\end{array}$ & $\begin{array}{c}1.957 \\
(1.191)\end{array}$ & $\begin{array}{c}-0.089 \\
(-1.040)\end{array}$ \\
\hline Firms, Subsample & 0.226 & $\begin{array}{c}0.238 \\
(0.709)\end{array}$ & $\begin{array}{c}1.822 \\
(1.972)^{*}\end{array}$ & $\begin{array}{c}2.711 \\
(1.722)^{*}\end{array}$ & $\begin{array}{c}0.304 \\
(0.428)\end{array}$ & $\begin{array}{c}1.741 \\
(2.039)^{* *}\end{array}$ & $\begin{array}{c}-0.000 \\
(-0.001)\end{array}$ \\
\hline Employment, Subsample & 0.171 & $\begin{array}{c}0.013 \\
(0.025)\end{array}$ & $\begin{array}{c}1.807 \\
(1.247)\end{array}$ & $\begin{array}{c}2.219 \\
(0.898)\end{array}$ & $\begin{array}{c}1.244 \\
(1.117)\end{array}$ & $\begin{array}{c}0.347 \\
(0.259)\end{array}$ & $\begin{array}{c}-0.068 \\
(-0.965)\end{array}$ \\
\hline
\end{tabular}

\section{Note:}

*Indicates significance at 10 percent level.

**Indicates significance at 5 percent level.

***Indicates significance at 1 percent level 
Table 6: Robustness Check for GROWTH Regression

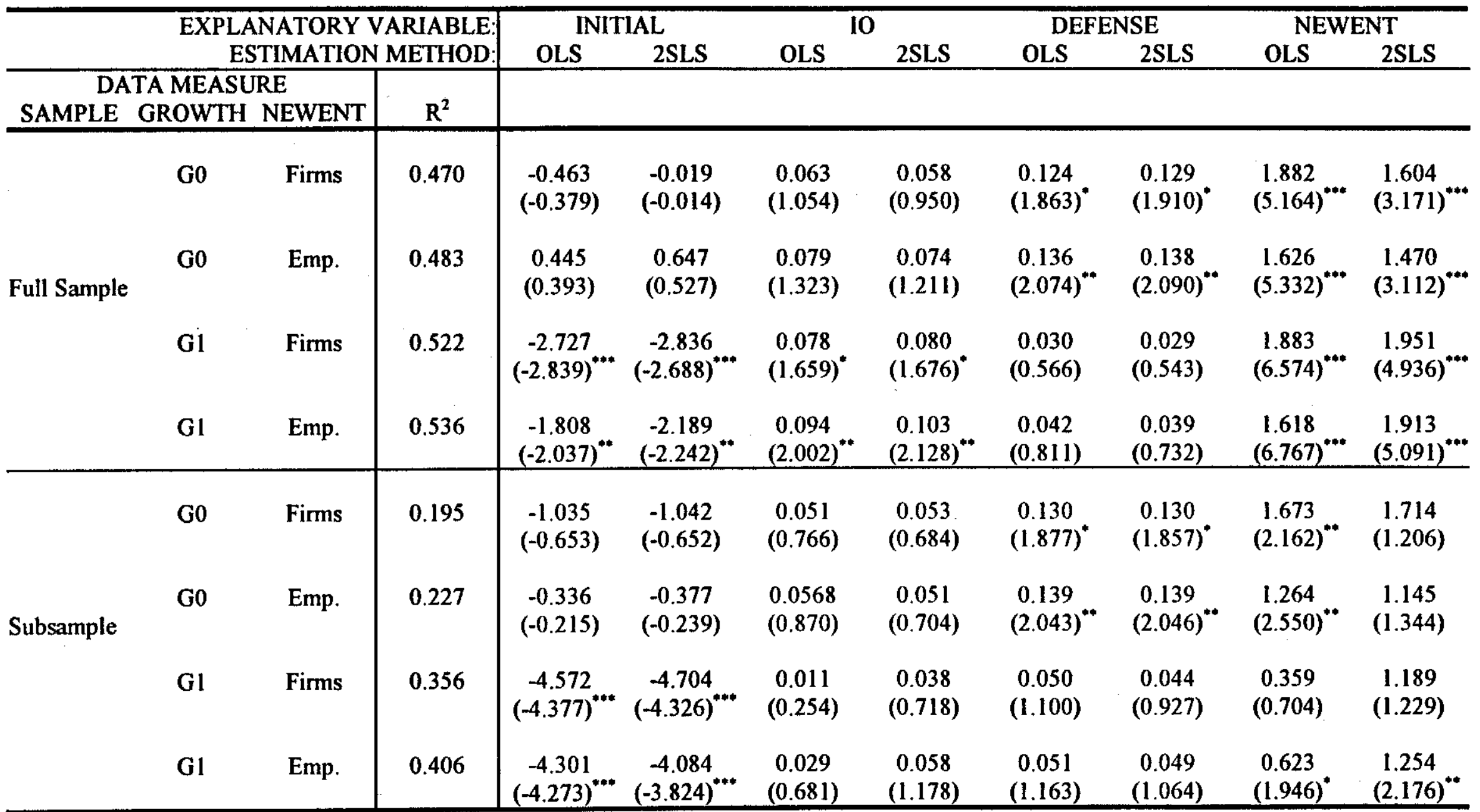

Note: $t$ statistics are given in parentheses. G0 refers to growth in real income, and G1 refers to growth in food income.

*Indicates significance at 10-percent level.

**Indicates significance at 5-percent level.

***Indicates significance at 1-percent level. 
Table 7: Exclusion Restrictions

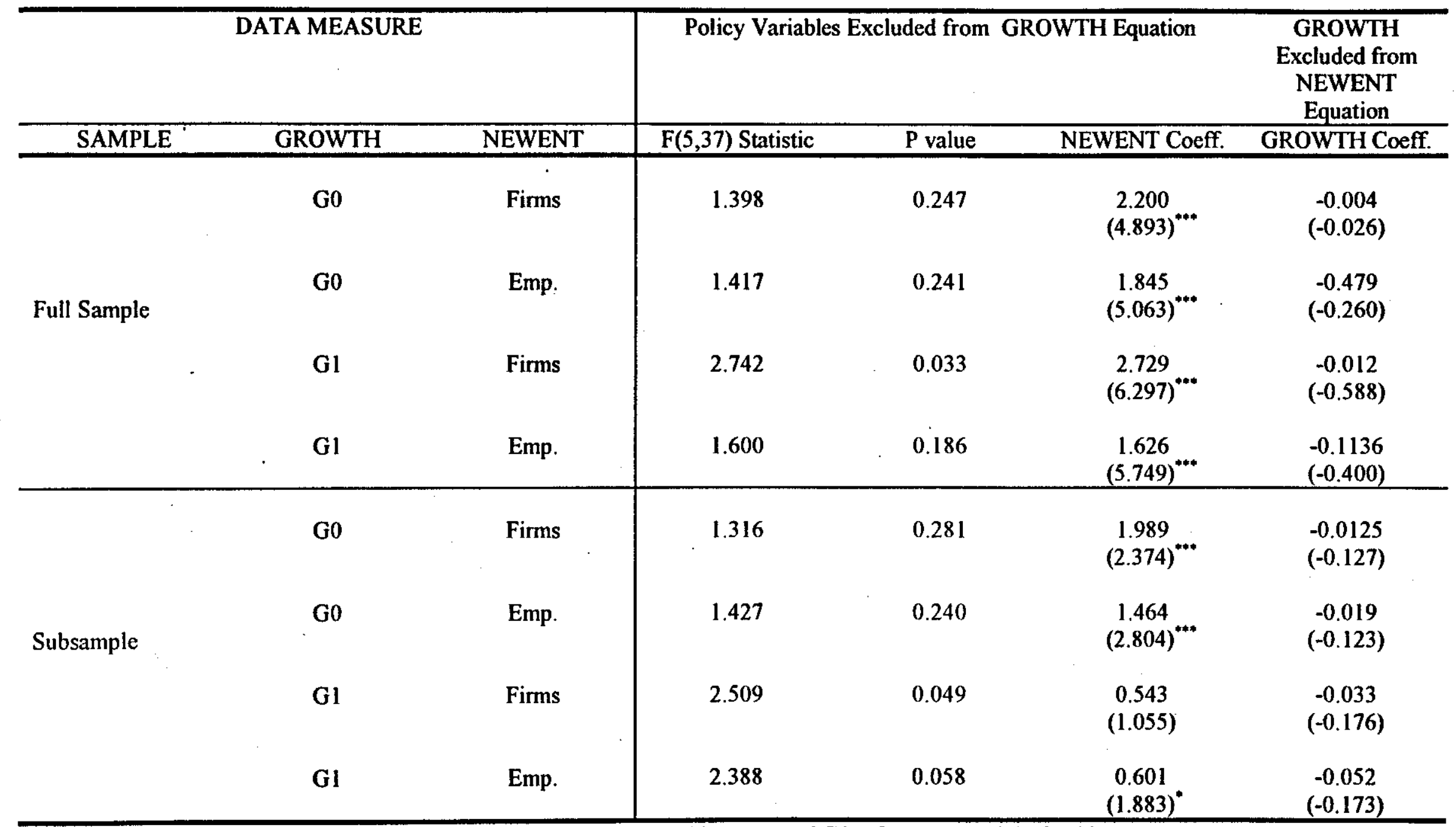

Note: $t$ statistics are given in parentheses. $G 0$ refers to growth in real income, and Gl refers to growth in food income.

*Indicates significance at 10 -percent level.

**Indicates significance at 5-percent level.

***Indicates significance at 1-percent level. 
Table 8: Dichotomization by Voting Patterns

\begin{tabular}{l|ccc}
\hline Variable & Red Belt & Non-Red Belt & p value \\
\hline G0 & $-10.16 \%$ & $-3.97 \%$ & 0.002 \\
G1 & $-4.16 \%$ & $-0.54 \%$ & 0.021 \\
NEWENT, Firms & 3.28 & 5.29 & 0.003 \\
NEWENT, Emp. & 7.42 & 9.5 & 0.011 \\
TPRIV & 0.552 & 0.615 & 0.184 \\
LPRIV & 0.534 & 0.643 & 0.001 \\
PRIVE & 0.364 & 0.629 & 0.001 \\
CONTROL & 0.514 & 0.6 & 0.129 \\
TAX & 0.228 & 0.215 & 0.172 \\
\hline
\end{tabular}

Note: $\mathrm{G} 0$ refers to growth in real income, and $\mathrm{Gl}$ refers to growth in food income. p-values are reported for the 1-sided t-test that the mean statistics for Red-Belt measures are insignificantly different from their NonRed-Belt counterparts. The test assumes unequal variances. 
Appendix Table A1: Policy and Initial Conditions

\begin{tabular}{|c|c|c|c|c|c|c|c|c|}
\hline Region & TPRIV & LPRIV & PRICE & CONTROL & $\operatorname{Tax}$ & Initial & 10 & Defense \\
\hline Karelian & 0.4 & 0.599 & 0.638 & 0.8 & 0.241 & 3.43 & -13.38 & 4.3 \\
\hline Murmansk & 0.4 & 0.734 & 0.426 & 0.6 & 0.191 & 3.79 & 7.16 & 5.7 \\
\hline St. Petersburg & 1.0 & 0.684 & 0.489 & 0.8 & 0.225 & 2.66 & 7.50 & 34.4 \\
\hline Kaliningrad & 0.4 & 0.659 & 0.851 & 0.6 & 0.216 & 2.47 & -28.05 & 15.9 \\
\hline Novgorod & 0.6 & 0.609 & 0.766 & 0.8 & 0.171 & 2.51 & 7.30 & 39.2 \\
\hline Bryansk & 0.4 & 0.616 & 0.277 & 0.4 & 0.197 & 2.66 & 5.04 & 36 \\
\hline Ivanovo & 0.6 & 0.461 & 0.702 & 0.6 & 0.200 & 1.75 & 21.13 & 1.7 \\
\hline Kaluga & 0.8 & 0.511 & 0.149 & 0.6 & 0.193 & 2.74 & 1.61 & 46.9 \\
\hline Kostroma & 0.6 & 0.312 & 0.979 & 0.4 & 0.196 & 2.56 & 6.49 & 13.8 \\
\hline Moscow & 1.0 & 0.836 & 1.000 & 0.6 & 0.182 & 4.60 & 8.36 & 24.4 \\
\hline Oryol & 0.6 & 0.531 & 0.021 & 0.4 & 0.164 & 4.04 & 8.27 & 13 \\
\hline Ryazan & 1.0 & 0.357 & 0.787 & 0.4 & 0.257 & 2.43 & 6.03 & 27.6 \\
\hline Smolensk & 0.6 & 0.557 & 0.213 & 0.2 & 0.211 & 2.47 & 7.66 & 21.1 \\
\hline Tula & 0.8 & 0.614 & 0.681 & 0.2 & 0.186 & 3.06 & 12.08 & 33.3 \\
\hline Yaroslavl & 0.6 & 0.671 & 0.319 & 0.4 & 0.247 & 2.86 & 12.66 & 22.3 \\
\hline Mariy-El & 0.2 & 0.489 & 0.447 & 1.0 & 0.288 & 2.63 & 1.60 & 45.7 \\
\hline Cordovan & 0.2 & 0.397 & 0.128 & 0.6 & 0.233 & 2.00 & 11.54 & 15.8 \\
\hline Chuvash & 0.4 & 0.672 & 0.170 & 0.6 & 0.259 & 2.16 & 12.69 & 19.9 \\
\hline Kirov & 0.4 & 0.666 & 0.745 & 0.6 & 0.201 & 2.54 & 3.79 & 31.4 \\
\hline Nizhniy Novgorod & 1.0 & 0.614 & 0.468 & 0.4 & 0.264 & 2.76 & 11.02 & 32.4 \\
\hline Voronezh & 0.6 & 0.568 & 0.298 & 0.4 & 0.215 & 2.39 & -4.11 & 40.2 \\
\hline Kursk & 0.6 & 0.602 & 0.106 & 0.4 & 0.245 & 2.59 & 0.42 & 13.9 \\
\hline Lipetsk & 0.4 & 0.664 & 0.191 & 0.2 & 0.313 & 3.03 & 10.42 & 8.1 \\
\hline Tatarstan & 0.4 & 0.507 & 0.234 & 1.0 & 0.347 & 3.36 & 11.34 & 30.1 \\
\hline Astrakhan & 0.4 & 0.536 & 0.255 & 0.6 & 0.204 & 2.23 & -19.56 & 23.1 \\
\hline Volgograd & 0.6 & 0.578 & 0.085 & 0.2 & 0.270 & 2.32 & 10.01 & 20.9 \\
\hline Penza & 0.8 & 0.573 & 0.532 & 0.8 & 0.178 & 2.12 & 5.11 & 24.4 \\
\hline Samara & 1.0 & 0.637 & 0.894 & 0.4 & 0.311 & 2.65 & 11.79 & 34.2 \\
\hline Saratov & 1.0 & 0.658 & 0.830 & 0.4 & 0.210 & 2.57 & 6.47 & 32.3 \\
\hline Ulyanovsk & 0.2 & 0.434 & 0.043 & 0.6 & 0.258 & 3.90 & 8.28 & 34.2 \\
\hline Adygey & 0.6 & 0.536 & 0.617 & 1.0 & 0.143 & 2.10 & 16.95 & 4 \\
\hline Kabardin Balkar & 0.2 & 0.480 & 0.362 & 1.0 & 0.147 & 2.07 & 3.77 & 18.7 \\
\hline North Osetian & 0.2 & 0.361 & 0.809 & 1.0 & 0.189 & 1.87 & 3.04 & 33.1 \\
\hline Udmurt & 0.8 & 0.720 & 0.383 & 0.6 & 0.218 & 2.31 & 7.25 & 57 \\
\hline Kurgan & 0.8 & 0.589 & 0.915 & 0.2 & 0.214 & 1.89 & 0.83 & 22.4 \\
\hline Perm & 0.6 & 0.852 & 0.936 & 0.2 & 0.225 & 2.32 & 11.96 & 37.8 \\
\hline Sverdlovsk & 0.4 & 0.765 & 0.574 & 0.4 & 0.247 & 2.94 & 16.08 & 32.5 \\
\hline Chelyabinsk & 0.6 & 0.781 & 0.596 & 0.4 & 0.238 & 2.23 & 21.79 & 22.3 \\
\hline Novosibirsk & 0.6 & 0.499 & 0.511 & 0.2 & 0.273 & 1.55 & 0.91 & 45.3 \\
\hline Omsk & 0.6 & 0.366 & 0.064 & 0.6 & 0.262 & 3.08 & 5.45 & 42.5 \\
\hline Tomsk & 0.4 & 0.677 & 0.957 & 0.4 & 0.228 & 2.78 & 8.27 & 12.8 \\
\hline Tyumen & 0.4 & 0.494 & 0.660 & 1.0 & 0.057 & 6.00 & 15.02 & 13.2 \\
\hline Buryat & 0.8 & 0.622 & 0.340 & 0.6 & 0.214 & 2.28 & 4.71 & 21.8 \\
\hline Primorskiy & 0.6 & 0.848 & 0.723 & 0.4 & 0.237 & 1.63 & -10.10 & 15.9 \\
\hline Khabarovsk & 0.6 & 0.642 & 0.404 & 0.6 & 0.243 & 2.35 & 3.77 & 28.6 \\
\hline Kamchatka & 0.6 & 0.665 & 0.872 & 1.0 & 0.169 & 3.24 & -71.64 & 2.5 \\
\hline Magadan & 0.8 & 0.669 & 0.553 & 0.8 & 0.210 & 3.38 & 0.62 & 41.4 \\
\hline$\overline{\text { Average }}$ & 0.587 & 0.594 & 0.511 & 0.562 & 0.222 & 2.71 & 4.03 & 25.49 \\
\hline Median & 0.600 & 0.609 & 0.511 & 0.600 & 0.216 & 2.56 & 7.16 & 24.40 \\
\hline Standard Deviation & 0.234 & 0.127 & 0.292 & 0.252 & 0.047 & 0.80 & 14.52 & 13.11 \\
\hline Minimum & 0.200 & 0.312 & 0.021 & 0.200 & 0.057 & 1.55 & -71.64 & 1.70 \\
\hline Maximum & 1.000 & 0.852 & 1.000 & 1.000 & 0.347 & 6.00 & 21.79 & 57.00 \\
\hline
\end{tabular}


Figure 1: Unconditional Correlations Between Growth and New-Enterprise Formation

\section{A: Full Sample}

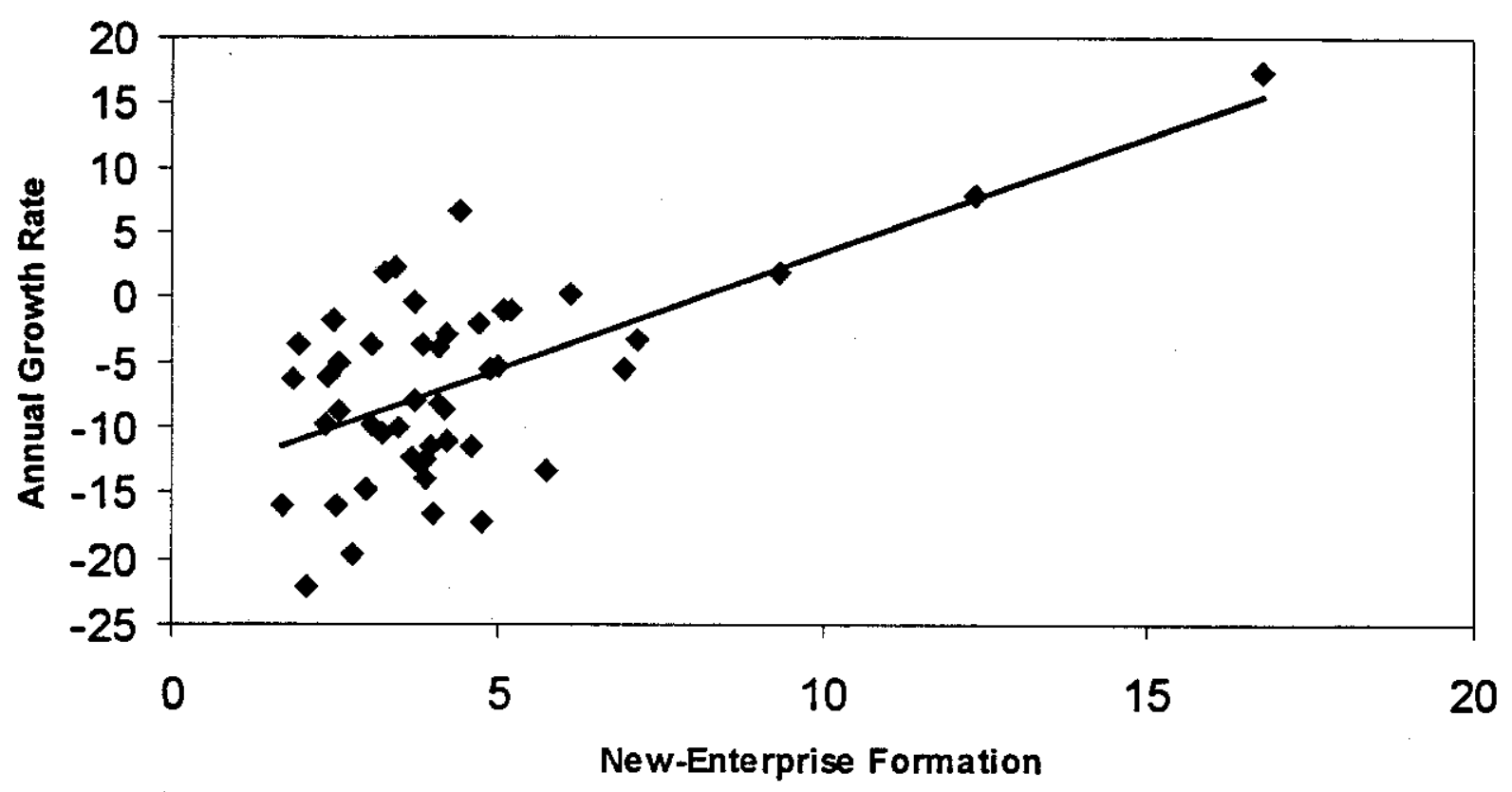

B: Outliers Removed

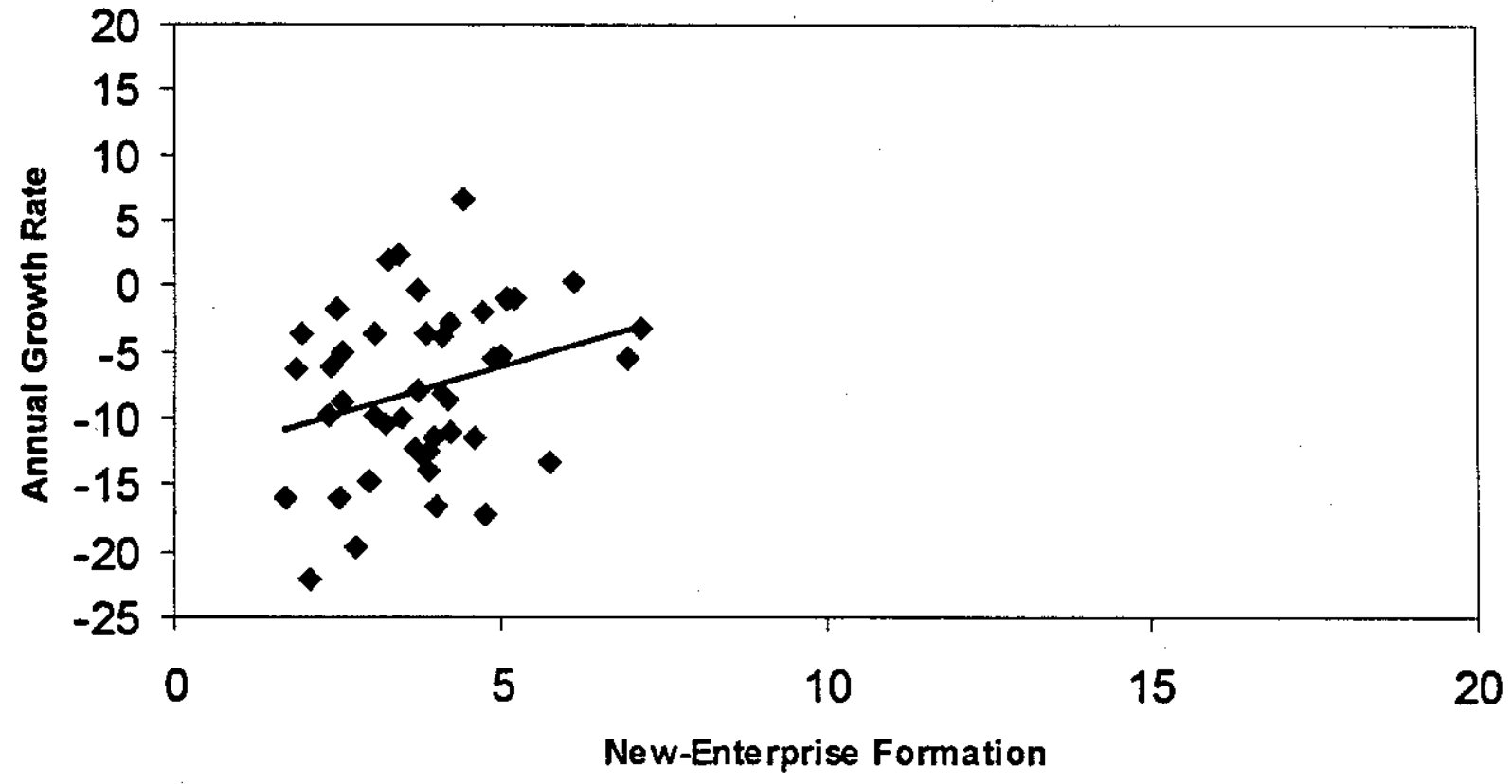


Figure 2: Correlations Between Unexplained Growth and New-Enterprise Formation

\section{A: Full Sample}

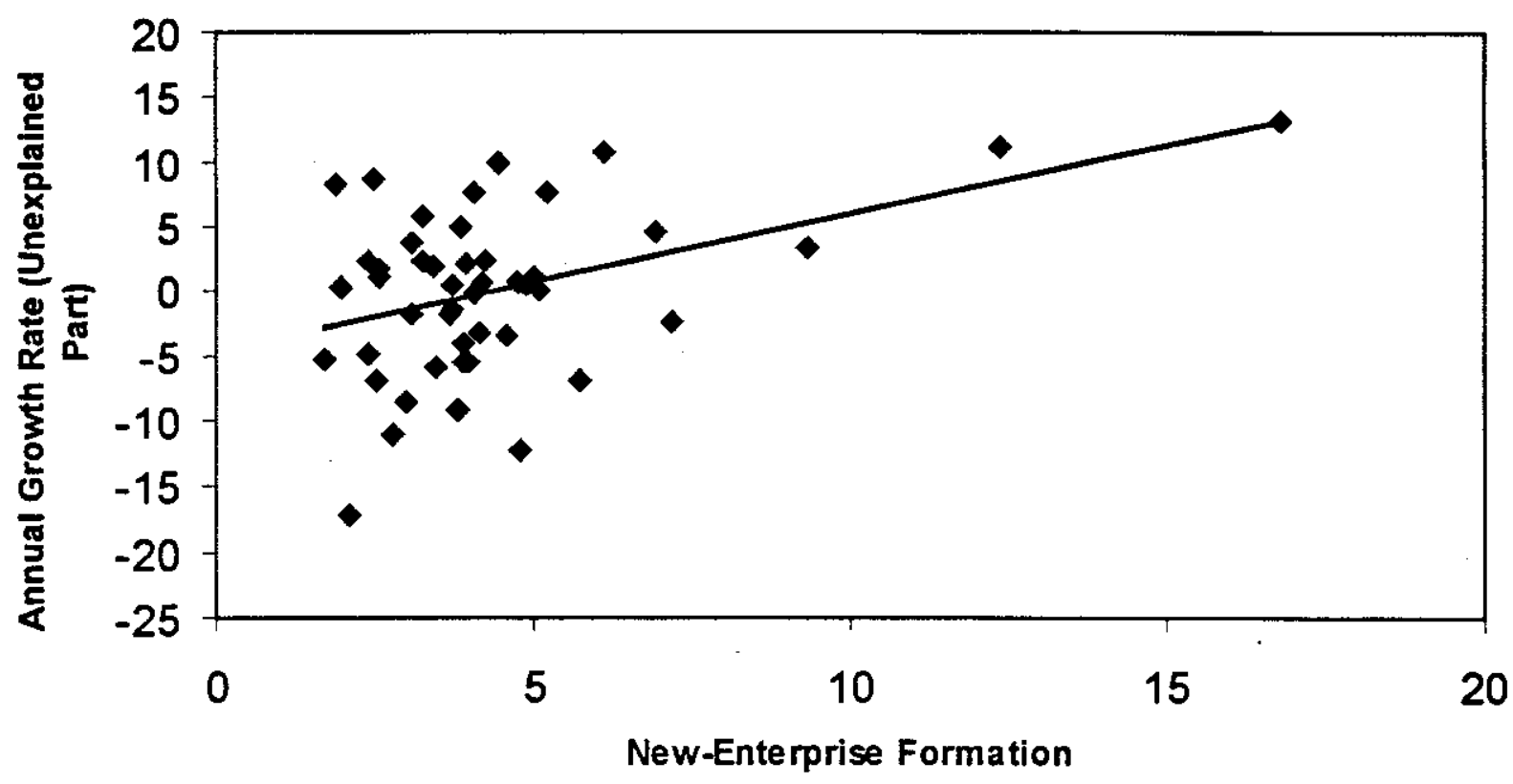

B: Outliers Removed

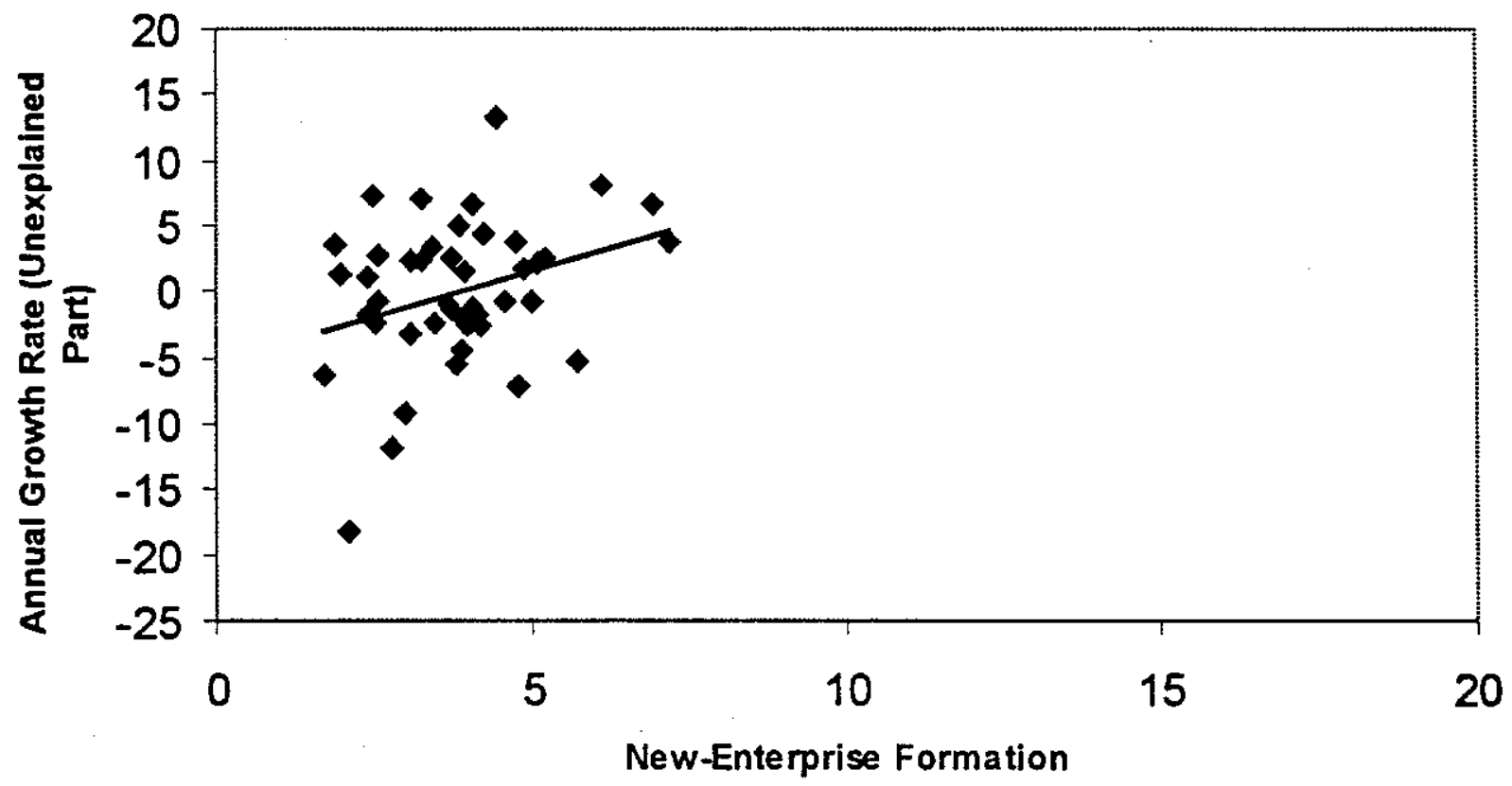


Figure 3: TAX and CONTROL

\section{A: Full Sample}

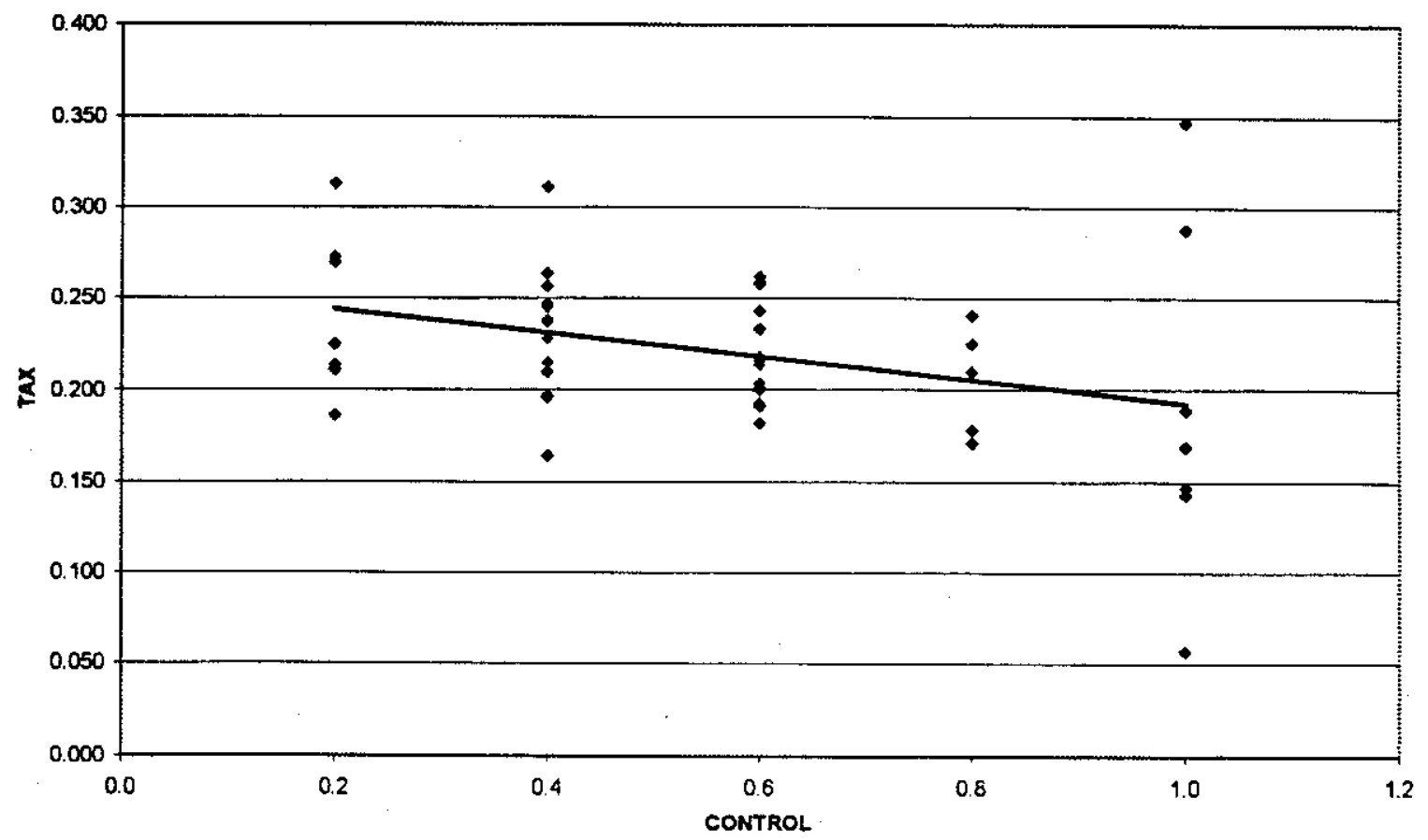

\section{B: Predators Excluded}

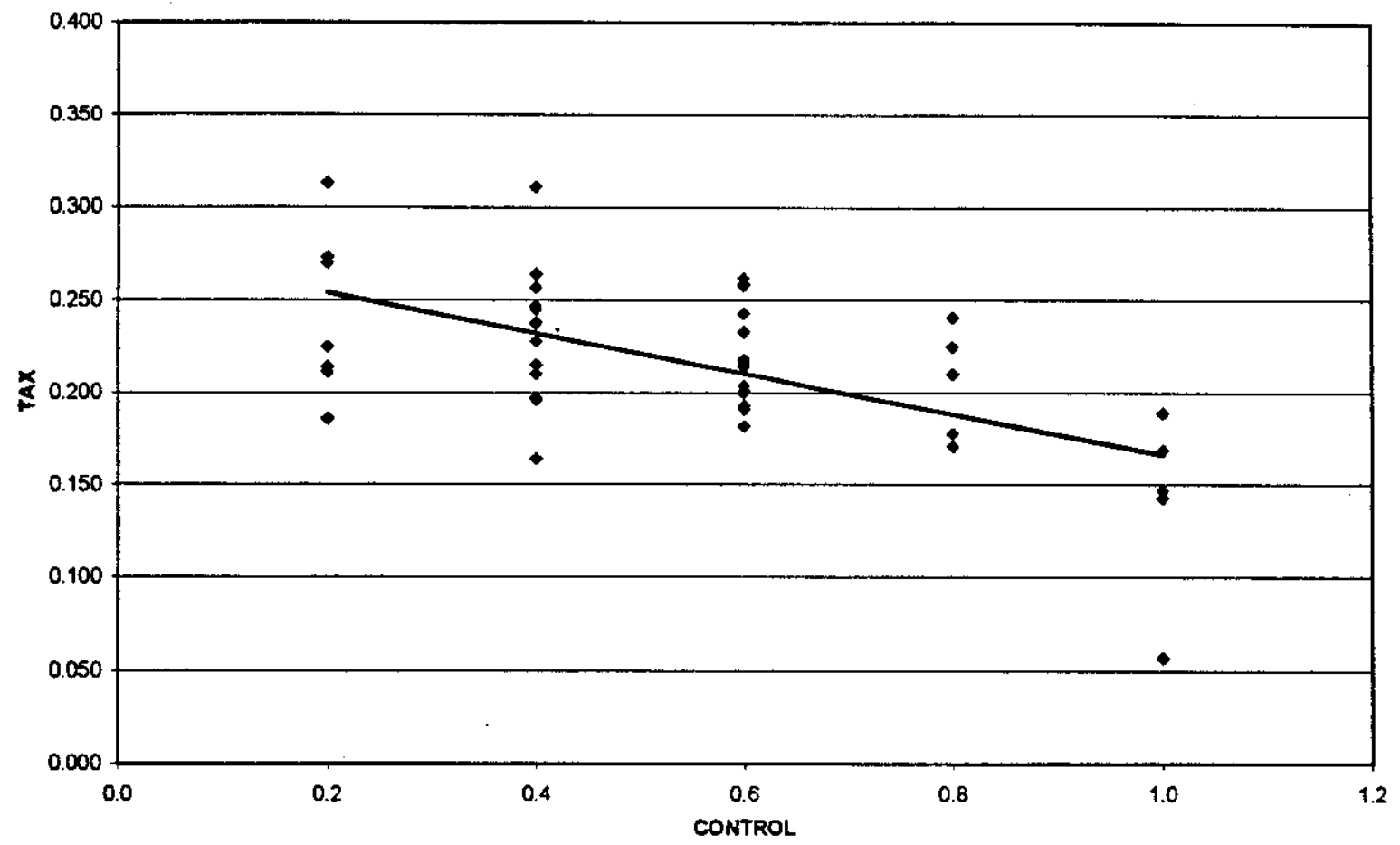

